\title{
Alteration of the nutrient uptake by the udder over an extended milking interval in dairy cows
}

\author{
J. Guinard-Flament, ${ }^{*} \dagger^{1}$ S. Lemosquet, $\dagger^{*}$ E. Delamaire, $\dagger^{*}$ G. Le Bris, $\dagger^{\star}$ P. Lamberton, $\dagger^{\star}$ and C. Hurtaud $\dagger^{\star}$ \\ ${ }^{*}$ Agrocampus Ouest, UMR1080 Production du Lait, F-35042 Rennes cedex, France \\ †INRA, UMR1080 Production du Lait, F-35590 Saint-Gilles, France
}

\begin{abstract}
Little is known about modifications of the mammary utilization of nutrients circulating in blood plasma when milk yield is strongly decreased by once-daily milking. A trial was carried out to describe the mammary nutritional adjustments linked to the downregulation of milk synthesis as milk accumulated over an extended milking interval in the bovine udder. Three Holstein dairy cows yielding $34.0 \mathrm{~kg} / \mathrm{d}$ of milk were fitted with an ultrasound flow probe around the left external pudic artery and with catheters inserted into the left carotid and milk vein to estimate mammary blood flow (MBF) and mammary uptake of acetate, $\beta$-hydroxybutyrate, nonesterified fatty acids, glycerol, glucose, $\mathrm{O}_{2}$, and $\mathrm{CO}_{2}$ release. The trial was carried out over 2 consecutive weeks, with wk 2 repeating wk 1 . Cows were milked twice daily at 12 -h milking intervals. On d 3, cows were milked at $0630 \mathrm{~h}$ and were not milked for $36 \mathrm{~h}$ until $\mathrm{d} 4$ at $1830 \mathrm{~h}$. Over the following days, twice-daily milking was resumed using 12-h milking intervals. Each halfudder was milked separately. Secretion rates of milk and milk proteins decreased $67 \%$ during the 12-to-36-h interval of milk accumulation, whereas that of milk fat fell 30\%. Timing of changes in MBF and lactose levels in blood plasma was concomitant and significant after 19.5 and $21.5 \mathrm{~h}$ of milk accumulation in the udder, respectively. The MBF decreased, most likely because the usual increases in MBF no longer occurred when the udder was full of milk. After $24 \mathrm{~h}$ of milk accumulation, MBF did not increase further when cows lay down, and did not increase as usual $3 \mathrm{~h}$ after a meal, suggesting a possible physical effect of milk accumulated in the udder on MBF, complementing metabolic regulation. Mammary uptake or release of nutrients was lowered before $24 \mathrm{~h}$ for glucose, acetate, and $\beta$-hydroxybutyrate and after $24 \mathrm{~h}$ for total glycerol, $\mathrm{O}_{2}$, and $\mathrm{CO}_{2}$, mostly associated with the impaired $\mathrm{MBF}$. However, these decreases ranged from 12 to $17 \%$, and cannot entirely
\end{abstract}

Received February 14, 2011.

Accepted July 24, 2011.

${ }^{1}$ Corresponding author: Jocelyne.Flament@agrocampus-ouest.fr explain the -45 and $-20 \%$ decreases in milk secretion rates observed during the entire $36 \mathrm{~h}$ of milk accumulation, thus confirming the primary role of intramammary metabolic regulation in the downregulation of milk secretion. The larger amount of nutrients taken up by the udder could explain the enhanced milk fat levels, involving a strongly modified metabolic fate of nutrients.

Key words: dairy cow, milk accumulation, mammary gland, nutrient uptake

\section{INTRODUCTION}

Among management practices that modify milk production in dairy cows, once-daily milking (ODM) is of interest to provide a better understanding of how the mammary gland uses nutrients circulating in blood plasma for milk synthesis. Once-daily milking strongly decreases milk yield and should modify nutrient needs of the mammary gland for milk synthesis. The amount of milk produced by dairy cows fell by an average of 20 to $30 \%$ from the first day of ODM application with slight modifications in milk composition (Davis et al., 1999; Rémond and Pomiès, 2005). Some of the changes in milk composition are related to the induced disruption of the mammary epithelium, leading to increased exchange between alveolar and blood plasma compartments. Lactose content decreased in milk and increased in blood plasma (Stelwagen et al., 1994a; Stelwagen et al., 1998). Similarly, protein content could increase in milk due to increases in whey proteins such as serum albumin (Delamaire and Guinard-Flament, 2006b; Guinard-Flament et al., 2007a). In contrast, some milk composition changes, such as for milk fat, could be related to different regulatory mechanisms governing the aqueous phase of milk and ultimately increasing milk fat content (Davis et al., 1999; Rémond and Pomiès, 2005).

Several experiments have aimed to explain milk yield and composition changes in response to ODM by studying nutrient flow to the udder and nutrient extraction by the udder (Delamaire and Guinard-Flament, 2006a,b; Guinard-Flament et al., 2007a). However, the measurements have all been carried out after $6 \mathrm{~d}$ of 
ODM when the mammary gland has adapted to its new milking frequency, and have not made it possible to determine the mammary adjustments linked to the downregulation of milk synthesis. Studies examining the short-term effects of intramammary milk accumulation have mostly only described blood supply to the udder (Stelwagen et al., 1994b; Farr et al., 2000), rarely tackling nutrients and mammary blood flow (MBF; Kuhn and Linzell, 1970; Fleet and Peaker, 1978), and only a few nutrients have been assessed to understand the nutritional mechanisms that lead to decreased milk production (glucose, Kuhn and Linzell, 1970; glucose, acetate, lactate, and oxygen, Fleet and Peaker, 1978). In addition, these studies were performed on goats, which showed only moderate changes in milk yield compared with dairy cows (Komara et al., 2009). In the first $24 \mathrm{~h}$ after cessation of milking in goats, no significant changes in milk secretion and MBF were observed (Fleet and Peaker, 1978). In contrast, and also in goats, Farr et al. (2000) reported lower MBF after 26 to $28 \mathrm{~h}$ of intramammary milk accumulation, whereas Stelwagen et al. (1994b) demonstrated that MBF began to decrease after $21 \mathrm{~h}$ of milk accumulation (i.e., roughly the same time that mammary epithelium became disrupted and milk secretion began to decrease). After d 1 of cessation of milking, the glucose and acetate uptakes fell in goats due to decreases in both MBF and arteriovenous differences (AVD) in concentrations, whereas the fall in oxygen consumption was related to the decrease in MBF alone (Fleet and Peaker, 1978).

Thus, little information is available on changes in mammary uptakes of nutrients circulating in the blood plasma as milk accumulates in the udder of dairy cows. In addition to the availability of nutrients in the arterial pool, mammary net uptakes of nutrients depend on metabolic activity within the udder and on MBF, both modified during ODM. The objective of the present study was to characterize the acute changes in mammary uptakes of the major precursors of milk fat and lactose synthesis (acetate, BHBA, NEFA, glycerol, and glucose) and mammary oxidative metabolism $\left(\mathrm{O}_{2}\right.$ and $\mathrm{CO}_{2}$ ) during 36-h intramammary milk accumulation. To better understand MBF variations, the timing of changes in $\mathrm{MBF}$ and mammary epithelium permeability was determined, and variations in $\mathrm{MBF}$ were examined according to the cow's position (supine or upright) as milk accumulates in the udder.

\section{MATERIALS AND METHODS}

\section{Cow Management and Experimental Design}

Three Holstein dairy cows averaging $632 \pm 39 \mathrm{~kg}$ of $\mathrm{BW}$ and $141 \pm 2 \mathrm{DIM}$ and yielding $34.0 \pm 2.2 \mathrm{~kg} / \mathrm{d}$ of milk at the start of the experiment were used according to National legislation on animal care (A35802). The cows were in second or third lactation, and were surgically prepared $43 \pm 3 \mathrm{~d}$ after calving to study the mammary uptake of nutrients in the left half-udder (Guinard et al., 1994; Delamaire and Guinard-Flament, 2006a,b). Venal blood was sampled from the subcutaneous abdominal vein with no occlusion of the pudic and perineal veins, as it is technically very difficult to occlude these two veins. Two permanent catheters were inserted into the left carotid and subcutaneous abdominal vein. An ultrasound flow probe (Probe 20 S, 20-mm i.d., cable length: $2.5 \mathrm{~m}$; Transonic Systems Inc., Ithaca, NY) was implanted around the left external pudic artery before the S-shaped bend in the artery. The flow probe cable was protected with Silastic tubing (Silclear medical-grade silicone tubing, 3-mm i.d., 6-mm o.d.; VWR International SAS, Briare, France). Two Dacron rings (Mersutures, TS53; Ethicon SAS, Issy-Les-Moulineaux, France) were placed along the cable and catheters and at the level of exteriorization to prevent any spread of infection.

The cows were housed indoors in individual stalls and fed a diet of $60 \%$ corn silage, $20 \%$ energy concentrate (containing 22\% barley, $21.5 \%$ wheat, $20 \%$ beet pulp, $17 \%$ fine wheat bran, $15 \%$ soybean meal, $2 \%$ molasses, and $2.5 \%$ minerals, all on a DM basis), $10 \%$ soybean meal, and $10 \%$ dehydrated alfalfa on a DM basis. The diet was calculated to meet the energy and protein requirements of cows milked twice daily (Institut National de la Recherche Agronomique, 1989). The cows were fed twice daily throughout the experiment and had free access to food for $8 \mathrm{~h}$ after each allocation (from 0630 to $1430 \mathrm{~h}$ and from 1830 to 0230 $h$ the next day).

The experiment was carried out during 2 consecutive weeks, with wk 2 repeating wk 1 . Cows were milked twice daily at 12-h milking intervals (0630 and 1830 h). On d 3, cows were milked at $0630 \mathrm{~h}$ and were not milked for $36 \mathrm{~h}$ until d 4 at $1830 \mathrm{~h}$. Over the following days, the cows were milked twice daily at 0630 and 1830 h. Each half-udder was milked separately during the experiment. No mastitis was observed. The SCC were $<400 \times 10^{3} / \mathrm{mL}$ on the $2 \mathrm{~d}$ before the 36 -h milking intervals.

\section{Sampling and Analyses}

Milk. Milk yield was recorded per half-udder at each milking. Every day, except the seventh day of each experiment week, the fat and protein contents and SCC of each half-udder were determined for each milking by infrared analysis (Milkoscan; Foss Electric A/S, Hillerød, Denmark). On d 3 and 4, $2 \mathrm{~L}$ of milk, representative 
of the milking of the left half-udder, was collected and stored at either $4^{\circ} \mathrm{C}$ for nitrogen analysis or $-20^{\circ} \mathrm{C}$ for subsequent milk composition analysis. The milk was analyzed for lactose using a colorimetric enzymatic reaction (lactose/D-galactose kit; Roche, Meylan, France) on a multiparameter analyzer (Kone Instruments Corp., Espoo, Finland), total nitrogen using the Kjeldahl procedure (Kjeldahl, 1883), and CN (precipitation at $\mathrm{pH} 4.6$ with $10 \%$ acetic acid and $1 \mathrm{M}$ sodium acetate). Milk fatty acids were extracted to determine the percentages of short-, medium-, and long-chain fatty acids, according to the method described by Bauchard and Duboisset (1983), using $0.5 \mathrm{~mL}$ of an ethanol/HCl (100:5 vol/vol) solution, followed by $5 \mathrm{~mL}$ of hexane. Briefly, milk fatty acids were transesterified with $1 \mathrm{~mL}$ of a methanol- $\mathrm{NaOH}$ solution $(100 / 2, \mathrm{vol} / \mathrm{wt})$, followed by $0.5 \mathrm{~mL}$ methanol/boron trifluoride $(100 / 20, \mathrm{vol} / \mathrm{vol})$ and $2 \mathrm{~mL}$ of hexane. Fatty acid methyl esters were then injected into a gas chromatograph (Varian 3400; Varian Inc., Les Ulis, France) equipped with an electron ionization detector. The carrier gas was helium. The oven temperature was increased from 70 to $220^{\circ} \mathrm{C}$ at $100^{\circ} \mathrm{C} /$ min and held for $32 \mathrm{~min}$. The injector and detector temperatures were 220 and $250^{\circ} \mathrm{C}$, respectively.

To estimate mammary epithelial permeability, milk $\mathrm{Na}^{+}$and $\mathrm{K}^{+}$concentrations were assayed using flame spectrometry (SpectraAA-20; Varian Inc.). The milk BSA concentration was measured using a radial immunodiffusion assay (rabbit anti-BSA antiserum; IDBiotech, St-Genès-Champanelle, France; Levieux, 1991).

Mammary Blood Flow. The MBF monitoring was continuous throughout the experiment. The sampling rate of the flowmeters (T208D; Transonic Systems Inc., Ithaca, NY) was fixed at $200 \mathrm{~Hz}$. The MBF and heart rate were averaged every minute and recorded using IOX software (emka Technologies SA, Paris, France). The cows were also fitted with a position-monitoring sensor to evaluate MBF in supine or upright position, as MBF varies according to the animal position.

Blood. Blood samplings were carried out only during the 36-h milking intervals. To obtain representative mammary venous blood, cows were sampled while they were standing to ensure as much venal blood as possible was leaving the udder via the subcutaneous abdominal vein (Delamaire and Guinard-Flament, 2006b). Blood samplings were carried out at 0.5, 1.5, $3.0,5.5,8.5,11.5,12.5,13.5,15.0,17.5,19.5,21.5,23.5$, $24.5,25.5,27,29.5,31.5,33.5$, and $35.5 \mathrm{~h}$ after the $\mathrm{d}-3$ milking. Blood samples were simultaneously collected from the carotid and subcutaneous abdominal vein using heparinized syringes $(7.5 \mathrm{~mL})$ and special blood gas heparinized syringes (2 mL, S-Monovette; Sarstedt AG \& Co., Nümbrecht, Germany). Concentrations of $\mathrm{O}_{2}$ and $\mathrm{CO}_{2}$ in blood were determined within 30 min after collection on a gas analyzer (ABL 625; Radiometer Copenhagen A/S, Brønshøj, Denmark). Other 7.5-mL blood samples were kept on ice until centrifugation at $2,500 \times g$ for $10 \mathrm{~min}$ at $4^{\circ} \mathrm{C}$. Plasma was stored at $-20^{\circ} \mathrm{C}$ for subsequent determination of mammary epithelial permeability (lactose in venous plasma) and mammary nutrient uptake (glucose, acetate, BHBA, NEFA, and total glycerol in arterial and venous plasma) based on colorimetric reactions with a multiparameter analyzer (Kone Instruments Corp.). Enzymatic kits were used for lactose ( $\beta$-galactosidase, $\beta$-galactose dehydrogenase; lactose/D-galactose kit; Roche), glucose (hexokinase, glucose-6-phosphate dehydrogenase; glucose hexokinase kit; Roche), NEFA [acetyl-coenzyme A (CoA) synthetase, acyl-CoA oxidase, peroxidase method; Wako kit; Oxoid S.A., Dardilly, France], total glycerol (lipase, glycerol kinase, glycerol-3-phosphate oxidase, peroxidase method; Biotrol Diagnostic SA, Chennevières-lèsLouvres, France), and BHBA (3-HB-dehydrogenase method; 3-D-hydroxybutyrate kit; Randox Laboratories Ltd., Crumlin, UK). Deproteinized plasma (with 50\%, $\mathrm{vol} / \mathrm{vol}$ perchloric acid by filtration) was used to measure acetate concentrations (acetyl-CoA synthetase, citrate synthetase, malate dehydrogenase method; Sigma, Saint-Quentin-Fallavier, France).

\section{Calculations and Statistical Analyses}

The 36-h milking interval was repeated twice on the 3 cows. However, data from one cow was discarded in wk 2 due to a failure of the blood flow cable $(\mathrm{n}=5)$. Nutrients, $\mathrm{O}_{2}$ and $\mathrm{CO}_{2}$ data were plotted using AVD or venoarterial differences (VAD) of concentrations, extraction rates $(\mathrm{AVD} /$ arterial concentration $\times 100)$, arterial flow [arterial concentration $\times \mathrm{MBF}$ or mammary plasma flow (MPF)] and mammary uptake or output (AVD or VAD $\times$ MBF or MPF). To describe mammary kinetics, MBF was averaged over $1 \mathrm{~h}$ (30 min before and 30 min after blood sampling), and MPF was calculated by correcting the MBF for hematocrit value. The MPF was only used for nutrients, not for $\mathrm{O}_{2}$ or $\mathrm{CO}_{2}$. Blood data were also divided into three 12 -h periods to analyze variations between periods. The area under the curve was determined for the 3 periods using the trapezoidal rule because of non-equidistant sampling, except for MBF, which was recorded every minute. The timing of changes in $\mathrm{MBF}$ was determined using the 1-h averaged MBF recorded during the 36-h intramammary milk accumulation compared with the MBF recorded over $36 \mathrm{~h}$ on $\mathrm{d} 1$ and 2 of the week when cows were milked twice daily at a 12 -h milking interval.

Milk and 12-h period blood data were analyzed using the MIXED procedure in SAS (SAS Institute Inc., Cary, NC). The statistical model included milk 
accumulation period for milk or 12 -h period for blood as fixed effects with repetition as a random effect to account for repeated measurements for each cow. The timing of changes in MBF and plasma lactose levels was analyzed on averaged data using the MIXED procedure considering kinetic time as a repeated measure. Results were expressed as least squares means with standard error of the mean. The threshold of significance was set at $P \leq 0.05$ and trends were noted at $P \leq 0.10$.

\section{RESULTS}

\section{Milk}

Milk accumulation in the udder reduced secretion rates for milk, milk fat and milk proteins. Comparing the 12 to 36 -h interval of milk accumulation to the 0 to 12-h interval, secretion rates of milk, fat, and proteins were decreased by $0.96 \mathrm{~kg} / \mathrm{h}, 18.3 \mathrm{~g} / \mathrm{h}$, and $30.2 \mathrm{~g} / \mathrm{h}$ (i.e., $-67 \%,-30 \%$, and $-68 \%$, respectively; Table 1 ). Milk fat content and SCS increased strongly during the 12-to-36-h accumulation interval $(+6.22$ percentage points and +3.3 units, i.e., $+152 \%$ and $+118 \%$, respectively), whereas milk protein content remained unchanged.

Similar variations were found for milk of the left-half udder (Table 2). The decrease in milk fat secretion rate was half the decrease in secretion rates of total milk and milk proteins ( -32 versus -67 and $-68 \%$, respectively). Milk fat content increased by 7.75 percentage points with slight modifications in fatty acid composition. The C16 and C4-to-C10 fatty acid contents decreased or tended to decrease to the benefit of $\mathrm{C} 18$ fatty acids $(+3.9$ percentage points $)$. The saturated fatty acid content decreased 3 percentage points. Milk lactose content did not vary significantly, but was numerically lower $(-1.45$ percentage point; $P=0.132)$. The ratio and contents of milk protein, $\mathrm{CN}$, and whey protein did not change.

\section{Indicators of Mammary Epithelium Permeability}

In response to 36 -h intramammary milk accumulation, the milk BSA content increased $48 \%$ (Table 3). The milk $\mathrm{Na}^{+}$content tended to increase, whereas the milk $\mathrm{K}^{+}$content remained unchanged. The milk $\mathrm{Na}^{+}-$ to- $\mathrm{K}^{+}$ratio did not vary significantly, although being numerically higher in milk collected after 36 -h milk accumulation $(P=0.103)$. Plasma lactose concentrations rose significantly after $21 \mathrm{~h}$ of intramammary milk accumulation (Figure 1).

\section{Mammary Blood Flow}

The MBF started to decrease from the second 12-h period of milk accumulation and decreased further over the third $12-\mathrm{h}$ period $(-0.44$ and $-1.38 \mathrm{~L} / \mathrm{min}$ compared with the first 12-h period, respectively; Table 4). To determine more precisely the time of change in MBF in response to milk accumulation, the MBF measured over the 36-h milk accumulation was compared with the MBF measured over $36 \mathrm{~h}$ on $\mathrm{d} 1$ and 2 as cows were milked at 12-h milking intervals (Figure 2). The MBF decreased after $19 \mathrm{~h}$ of milk accumulation in the udder. This decrease tended to be greater when cows were lying instead of standing $(-1.27$ vs. $-0.53 \mathrm{~L} / \mathrm{min}$, respectively; $\mathrm{SEM}=0.206 ; P=0.066)$. The time spent in the upright position ranged between 60 and $73 \%$, and did not vary significantly. Heart rates only tended to be higher during the night.

\section{Mammary Nutrient Utilization}

No variation in arterial concentrations of nutrients occurred, except an increase for glucose and total glycerol (Table 5), which were greater in the third 12 -h period of milk accumulation. Arteriovenous differences of concentrations did not vary significantly between periods for any nutrient. Extraction rates decreased for glucose, total glycerol, and acetate but not for BHBA. Extrac-

Table 1. Effect of milk accumulation in the udder on milk secretion rate and milk composition in dairy cows

\begin{tabular}{|c|c|c|c|c|}
\hline \multirow[b]{2}{*}{ Item } & \multicolumn{2}{|c|}{ Accumulation period } & \multirow[b]{2}{*}{ SEM } & \multirow{2}{*}{$\begin{array}{c}\text { Effect } \\
(P \text {-value })\end{array}$} \\
\hline & $0-12 \mathrm{~h}^{1}$ & $12-36 \mathrm{~h}^{2}$ & & \\
\hline Milk (kg/h) & 1.44 & 0.48 & 0.062 & 0.009 \\
\hline Milk fat $(\mathrm{g} / \mathrm{h})$ & 61.5 & 43.2 & 3.37 & 0.038 \\
\hline Milk protein $(\mathrm{g} / \mathrm{h})$ & 44.3 & 14.1 & 2.16 & 0.009 \\
\hline Fat content $(\%)$ & 4.09 & 10.31 & 1.104 & 0.055 \\
\hline Protein content (\%) & 3.16 & 3.02 & 0.169 & NS \\
\hline SCS & 2.8 & 6.1 & 0.37 & 0.035 \\
\hline
\end{tabular}

${ }^{1}$ Milk collected after a 12-h milking interval.

${ }^{2}$ Milk produced from 12 to $36 \mathrm{~h}$ post-milking (determined by calculating the difference between the 36 -h milk and the 12-h milk). 
Table 2. Effect of milk accumulation in the udder on milk composition from the left-half udder in dairy cows

\begin{tabular}{|c|c|c|c|c|}
\hline \multirow[b]{2}{*}{ Item } & \multicolumn{2}{|c|}{ Accumulation period } & \multirow[b]{2}{*}{ SEM } & \multirow{2}{*}{$\begin{array}{c}\text { Accumulation effect } \\
(P \text {-value })\end{array}$} \\
\hline & $0-12 \mathrm{~h}^{1}$ & $12-36 \mathrm{~h}^{2}$ & & \\
\hline Milk secretion rate $(\mathrm{kg} / \mathrm{h})$ & 0.69 & 0.23 & 0.037 & 0.018 \\
\hline \multicolumn{5}{|l|}{ Milk fat } \\
\hline $\mathrm{g} / \mathrm{h}$ & 29.1 & 19.7 & 2.80 & 0.046 \\
\hline$\%$ & 3.87 & 11.62 & 2.025 & 0.106 \\
\hline \multicolumn{5}{|l|}{ Milk fatty acids } \\
\hline C4 to $\mathrm{C} 10(\%)$ & 18.0 & 16.9 & 0.93 & 0.065 \\
\hline C14 (\%) & 13.6 & 13.1 & 0.31 & NS \\
\hline C16 (\%) & 37.2 & 34.9 & 1.53 & 0.034 \\
\hline $\mathrm{C} 18(\%)$ & 29.7 & 33.6 & 0.66 & 0.029 \\
\hline Saturated fatty acids (\%) & 75.4 & 72.4 & 0.64 & 0.014 \\
\hline \multicolumn{5}{|l|}{ Milk lactose } \\
\hline $\mathrm{g} / \mathrm{h}$ & 34.3 & 8.3 & 2.14 & 0.015 \\
\hline$\%$ & 4.90 & 3.45 & 0.306 & NS \\
\hline \multicolumn{5}{|l|}{ Milk protein } \\
\hline $\mathrm{g} / \mathrm{h}$ & 21.6 & 6.9 & 1.42 & 0.022 \\
\hline$\%$ & 3.08 & 2.97 & 0.094 & NS \\
\hline \multicolumn{5}{|l|}{$\mathrm{CN}$} \\
\hline $\mathrm{g} / \mathrm{h}$ & 17.5 & 5.3 & 1.33 & 0.023 \\
\hline$\%$ & 2.54 & 2.32 & 0.112 & NS \\
\hline \multicolumn{5}{|l|}{ Whey protein } \\
\hline $\mathrm{g} / \mathrm{h}$ & 4.0 & 1.5 & 0.25 & 0.025 \\
\hline$\%$ & 0.62 & 0.72 & 0.104 & NS \\
\hline \multicolumn{5}{|l|}{ Ratio } \\
\hline Milk CN/protein & 0.80 & 0.77 & 0.031 & NS \\
\hline Whey protein/CN & 0.26 & 0.31 & 0.052 & NS \\
\hline
\end{tabular}

${ }^{1}$ Milk collected after a 12-h milking interval.

${ }^{2}$ Milk produced from 12 to $36 \mathrm{~h}$ post-milking (determined by calculating the difference between the 36 -h milk and the 12-h milk).

tion rates were altered for glucose and total glycerol in the third 12 -h period $(-7.5$ and -9.6 percentage points between the first and third periods, respectively) due to higher arterial concentrations and numerically lower AVD. It was decreased for acetate from the second $12-\mathrm{h}$ period ( -7 percentage points) due to numerically lesser AVD. Arterial flow did not vary between periods for glucose and total glycerol, and decreased or tended to decrease over the third 12-h period for acetate, NEFA, and BHBA $(P=0.1051)$ in a similar range of variation to MBF (by about -27 vs. $-25 \%$, respectively). Mammary nutrient uptake (except NEFA) decreased as milk accumulated in the udder. It decreased or tended to decrease from the second 12-h period for glucose, acetate, and BHBA (by $-15,-12$, and $-18 \%$, respec- tively), whereas the only decrease noted at the third 12 -h period concerned total glycerol.

\section{Oxidative Mammary Metabolism}

The arterial concentration, AVD, and extraction rates of $\mathrm{O}_{2}$ did not change between periods in response to milk accumulation (Table 6). Mammary arterial flow of $\mathrm{O}_{2}$ decreased from the second 12-h period and decreased strongly during the third 12 -h period, whereas mammary $\mathrm{O}_{2}$ uptake decreased only from the third 12-h period. The arterial concentration and VAD of $\mathrm{CO}_{2}$ did not vary between periods. However, $\mathrm{CO}_{2}$ output by the udder tended to decrease in the third $12-\mathrm{h}$ period. The respiratory quotient remained unchanged,

Table 3. Effect of milk accumulation in the udder on indicators of mammary epithelium integrity in dairy cows (from the left-half udder milk)

\begin{tabular}{|c|c|c|c|c|}
\hline \multirow[b]{2}{*}{ Item } & \multicolumn{2}{|c|}{ Accumulation period } & \multirow[b]{2}{*}{ SEM } & \multirow{2}{*}{$\begin{array}{c}\text { Accumulation effect } \\
(P \text {-value })\end{array}$} \\
\hline & $0-12 \mathrm{~h}$ & 0-36 h & & \\
\hline $\mathrm{BSA}(\mathrm{mg} / \mathrm{L})$ & 200 & 295 & 19.2 & 0.031 \\
\hline $\mathrm{Na}^{+}(\mathrm{m} M)$ & 13.7 & 23.3 & 3.44 & 0.089 \\
\hline $\mathrm{K}^{+}(\mathrm{m} M)$ & 51.7 & 47.5 & 4.92 & NS \\
\hline Ratio $\mathrm{Na}^{+} / \mathrm{K}^{+}$ & 0.279 & 0.524 & 0.1306 & NS \\
\hline
\end{tabular}


Table 4. Effect of milk accumulation in the udder over $36 \mathrm{~h}$ on mammary blood flow (MBF) according to position (upright versus supine) of dairy cows

\begin{tabular}{|c|c|c|c|c|c|}
\hline \multirow[b]{2}{*}{ Item } & \multicolumn{3}{|c|}{ Accumulation period } & \multirow[b]{2}{*}{ SEM } & \multirow{2}{*}{$\begin{array}{l}\text { Period effect } \\
(P \text {-value })\end{array}$} \\
\hline & $0-12 \mathrm{~h}$ & $12-24 \mathrm{~h}$ & $24-36 \mathrm{~h}$ & & \\
\hline $\mathrm{MBF}(\mathrm{L} / \mathrm{min})$ & $5.50^{\mathrm{a}}$ & $5.06^{\mathrm{b}}$ & $4.12^{\mathrm{c}}$ & 1.052 & 0.001 \\
\hline MBF in upright position $(\mathrm{L} / \mathrm{min})$ & $5.20^{\mathrm{a}}$ & $4.98^{\mathrm{a}}$ & $4.20^{\mathrm{b}}$ & 1.032 & 0.005 \\
\hline MBF in supine position $(\mathrm{L} / \mathrm{min})$ & $5.93^{\mathrm{a}}$ & $5.20^{\mathrm{b}}$ & $3.95^{\mathrm{c}}$ & 1.129 & 0.003 \\
\hline Relative time in upright position (\%) & 60 & 72 & 73 & 4.7 & NS \\
\hline Heart rate (beats/min) & $67.6^{\mathrm{b}}$ & $73.0^{\mathrm{a}}$ & $67.3^{\mathrm{b}}$ & 2.82 & 0.059 \\
\hline
\end{tabular}

${ }^{\mathrm{a}-\mathrm{c}}$ Within each row, values with different superscript letters differ at $P<0.05$.

despite being numerically lower in the third 12 -h period (-0.14 units).

\section{DISCUSSION}

To gain deeper insights into the mammary utilization of nutrients circulating in blood plasma for the synthesis and secretion of milk compounds in response to ODM, the present study was designed to describe the mammary nutritional adjustments linked to the downregulation of milk synthesis as milk accumulated in the udder. We elected to study mammary nutrient uptake over a single time interval rather than several successive intervals to describe the activation of mammary adaptive mechanisms and pinpoint the key points of mammary use of nutrients. The trial was repeated a second time, but after a week-long interval to eliminate any residual effects of the first repetition (Wheelock et al., 1966). The time interval studied was $36 \mathrm{~h}$, which runs over the 24-h interval for ODM to amplify the peak of the phenomena measured and partly resolve the limited statistical power of the experimental set-up due to the small number of animals used $(\mathrm{n}=3)$ and the data losses caused by the breakage of a flowmeter probe in one animal.

\section{Timing of Changes in Mammary Epithelium Permeability and MBF}

The effects of 36-h intramammary milk accumulation on milk yield and composition were larger but in agreement with previous reports on cows switched to ODM

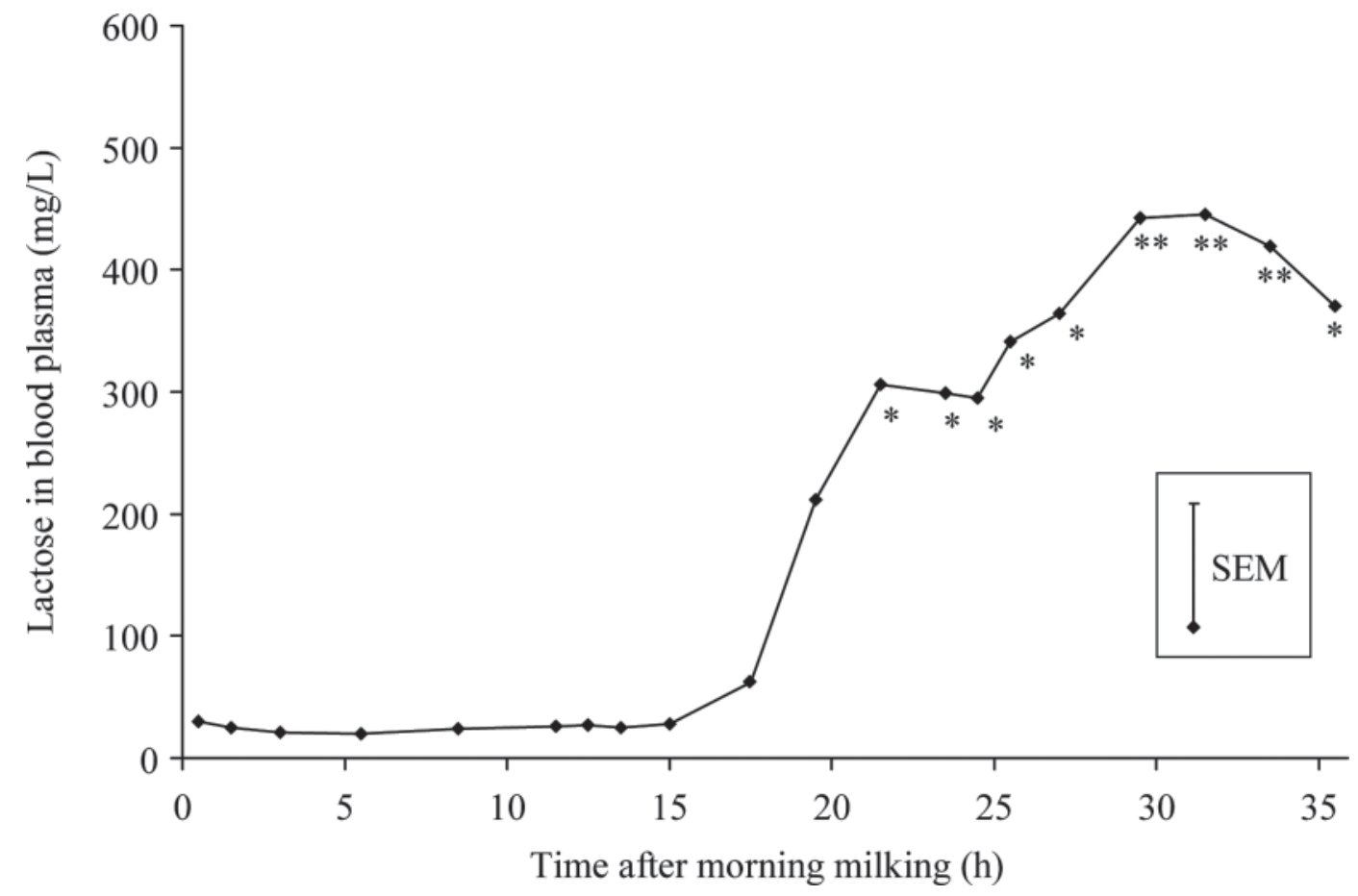

Figure 1. Lactose concentrations in blood plasma during 36 -h milk accumulation in the udder in dairy cows. $* *$ and $*=$ significantly different from lactose at time $0.5,1.5,3,5.5,8.5,11.5,12.5,13.5,15$, and $17.5 \mathrm{~h}$ after morning milking, at $P<0.01$ and 0.05 , respectively. 


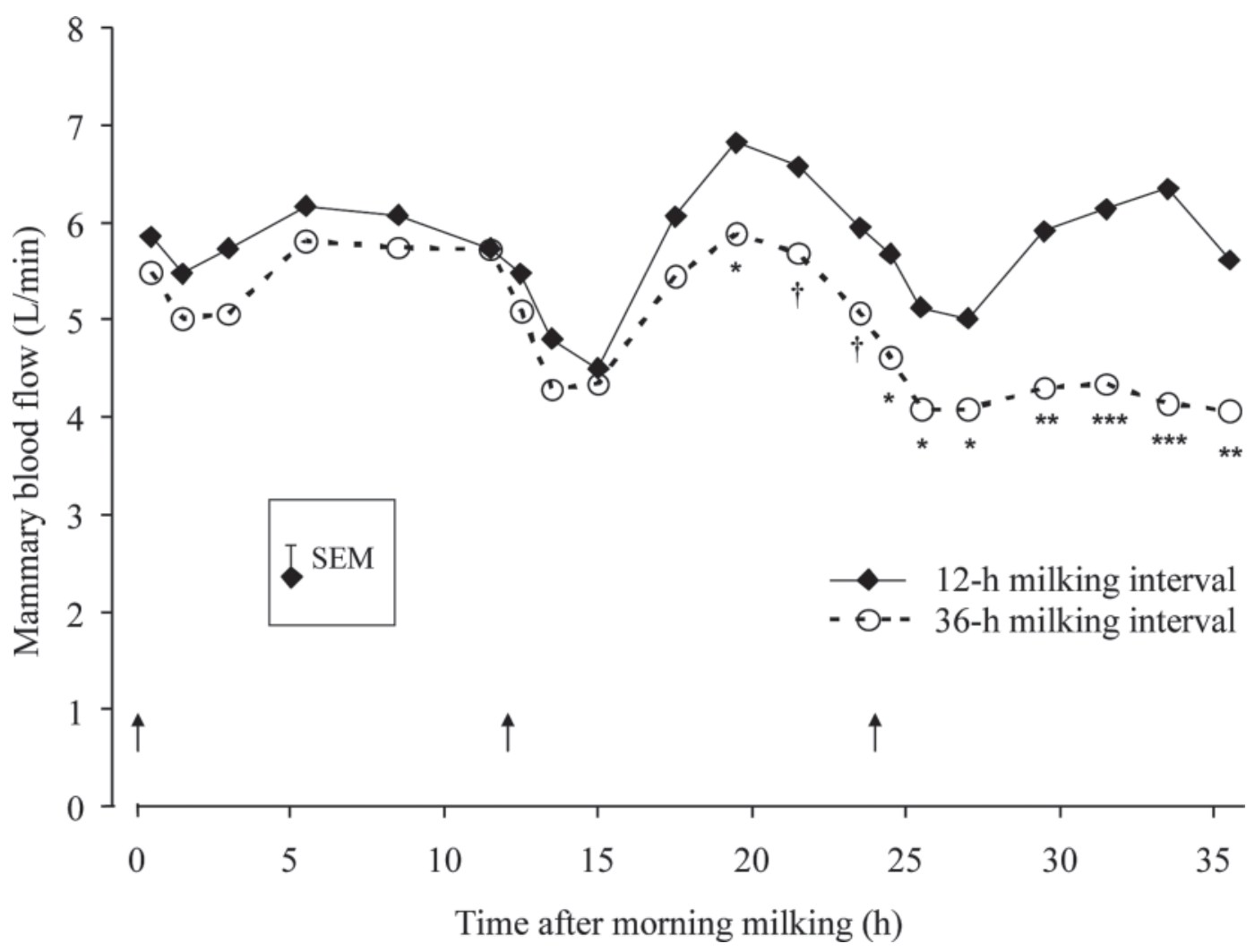

Figure 2. Mammary blood flow over $36 \mathrm{~h}$ in dairy cows milked every $12 \mathrm{~h}$ or after a 36 -h milking interval. $* * *, * *, *$, and $\dagger=$ significantly different at $P<0.001,0.01,0.05$, and 0.10 , respectively. Vertical arrows $(\uparrow)$ indicate time of feed distribution.

in short-term trials (Delamaire and Guinard-Flament, 2006b; Guinard-Flament et al., 2007a). Milk accumulation in the udder led to major and proportional decrease in milk and milk protein secretion rates that ranged 67 to $68 \%$ during the 12 -to-36-h interval (i.e., $45 \%$ when calculated over the entire 36 -h milk accumulation). Such variations in milk and milk protein secretion rates have already been described in dairy cows (roughly $-35 \%$; Wheelock et al., 1966) and goats (-48 and $-46 \%$, respectively; Ben Chedly et al., 2009). Milk fat secretion rate was affected less $(-30 \%$ during the 12-to-36-h interval), leading to an increase in milk fat content associated with slight increases in the proportion of $\mathrm{C} 18$ and unsaturated fatty acids. In the present study, no measurement of residual milk was performed after milking, which impairs the quality of the estimation of milk fat yield. However, similar variation in milk fat content in dairy cows after a 36 -h period of milk accumulation was observed when removing residual milk at each milking by giving an injection of 20 IU of oxytocin (Wheelock et al., 1966). The increase in milk fat content observed in the present study $(+2.1$ percentage points when calculated over the entire 36 - $h$ milk accumulation) was greater but remained consistent with the +1.3 percentage points reported by Wheelock et al. (1966).

When extended milking intervals were applied just once, the literature reports constant milk secretion rates up to $12 \mathrm{~h}$ or even $16 \mathrm{~h}$ of milk accumulation in the udder (Wheelock et al., 1966; Davis et al., 1998; Stelwagen et al., 2008) that subsequently decrease $(-16$ and $-21 \%$ at 18 and $24 \mathrm{~h}$ of milk accumulation, respectively; Stelwagen et al., 2008). After 16 h, continued milk accumulation distends the udder, causing many effects. The cause-effect relationships have not been clearly established, but the rate of milk secretion begins to decrease as mammary epithelium permeability increases with lactose leaking into the blood compartment (Stelwagen et al., 1997; Stelwagen, 2001). Our findings on plasma lactose, which indicate changes in mammary epithelium leakiness, are consistent with the above studies. In the present study, plasma lactose increased significantly from $21.5 \mathrm{~h}$ of milk accumulation in the udder versus $21 \mathrm{~h}$ in goats and $18 \mathrm{~h}$ in dairy cows (Stelwagen et al., 1994b and 1997, respectively).

As previously observed in goats (Stelwagen et al., 1994b), here, in cows, the effects of milk accumulation in the udder on plasma lactose and MBF proved con- 
Table 5. Time-course evolution in arterial concentrations, arteriovenous differences (AVD) of concentrations, extraction rates, arterial flows, and mammary uptake of glucose, acetate, BHBA, total glycerol, and NEFA during 36 -h milk accumulation in the udder in dairy cows

\begin{tabular}{|c|c|c|c|c|c|}
\hline \multirow[b]{2}{*}{ Item } & \multicolumn{3}{|c|}{ Accumulation period } & \multirow[b]{2}{*}{ SEM } & \multirow{2}{*}{$\begin{array}{c}\text { Period effect } \\
(P \text {-value })\end{array}$} \\
\hline & $0-12 \mathrm{~h}$ & $12-24 \mathrm{~h}$ & $24-36 \mathrm{~h}$ & & \\
\hline Plasma flow (L/min) & $3.81^{\mathrm{a}}$ & $3.54^{\mathrm{b}}$ & $2.86^{\mathrm{c}}$ & 0.753 & 0.001 \\
\hline \multicolumn{6}{|l|}{ Glucose } \\
\hline Arterial concentration $(\mathrm{m} M)$ & $3.37^{\mathrm{b}}$ & $3.41^{\mathrm{b}}$ & $4.23^{\mathrm{a}}$ & 0.089 & 0.002 \\
\hline $\operatorname{AVD}(\mathrm{m} M)$ & 0.95 & 0.88 & 0.86 & 0.038 & NS \\
\hline Extraction rate $(\%)$ & $28.1^{\mathrm{a}}$ & $26.2^{\mathrm{a}}$ & $20.6^{\mathrm{b}}$ & 0.74 & 0.007 \\
\hline Arterial flow $(\mathrm{mmol} / \mathrm{h})$ & 759 & 718 & 736 & 162.3 & NS \\
\hline Uptake $(\mathrm{mmol} / \mathrm{h})$ & $211^{\mathrm{a}}$ & $180^{\mathrm{b}}$ & $148^{\mathrm{c}}$ & 37.2 & 0.004 \\
\hline \multicolumn{6}{|l|}{ Total glycerol } \\
\hline Arterial concentration $(\mu M)$ & $75.1^{\mathrm{b}}$ & $81.5^{\mathrm{b}}$ & $96.6^{\mathrm{a}}$ & 4.92 & 0.027 \\
\hline $\operatorname{AVD}(\mu M)$ & 27.5 & 26.6 & 25.3 & 1.65 & NS \\
\hline Extraction rate $(\%)$ & $35.9^{\mathrm{a}}$ & $32.6^{\mathrm{a}}$ & $26.3^{\mathrm{b}}$ & 2.05 & 0.019 \\
\hline Arterial flow $(\mathrm{mmol} / \mathrm{h})$ & 17.0 & 17.2 & 16.4 & 3.49 & NS \\
\hline Uptake $(\mathrm{mmol} / \mathrm{h})$ & $6.18^{\mathrm{a}}$ & $5.65^{\mathrm{a}}$ & $4.38^{\mathrm{b}}$ & 0.853 & 0.034 \\
\hline \multicolumn{6}{|l|}{ Acetate } \\
\hline Arterial concentration $(\mathrm{m} M)$ & 2.06 & 2.22 & 1.98 & 0.106 & NS \\
\hline $\operatorname{AVD}(\mathrm{m} M)$ & 1.51 & 1.46 & 1.25 & 0.062 & NS \\
\hline Extraction rate (\%) & $74.6^{\mathrm{a}}$ & $67.6^{\mathrm{b}}$ & $65.4^{\mathrm{b}}$ & 2.29 & 0.049 \\
\hline Arterial flow $(\mathrm{mmol} / \mathrm{h})$ & $475^{\mathrm{a}}$ & $464^{\mathrm{a}}$ & $335^{\mathrm{b}}$ & 77.8 & 0.030 \\
\hline Uptake $(\mathrm{mmol} / \mathrm{h})$ & $353^{\mathrm{a}, a}$ & $309^{\mathrm{a}, b}$ & $218^{\mathrm{b}, c}$ & 55.9 & 0.007 \\
\hline \multicolumn{6}{|l|}{ BHBA } \\
\hline Arterial concentration $(\mathrm{m} M)$ & 1.19 & 1.34 & 1.21 & 0.118 & NS \\
\hline $\operatorname{AVD}(\mathrm{m} M)$ & 0.54 & 0.48 & 0.49 & 0.002 & NS \\
\hline Extraction rate (\%) & 46.3 & 39.2 & 42.2 & 3.17 & NS \\
\hline Arterial flow $(\mathrm{mmol} / \mathrm{h})$ & 278 & 292 & 203 & 79.8 & NS \\
\hline Uptake $(\mathrm{mmol} / \mathrm{h})$ & $122^{\mathrm{a}, a}$ & $100^{\mathrm{ab}, b}$ & $82^{\mathrm{b}, b}$ & 22.3 & 0.046 \\
\hline \multicolumn{6}{|l|}{ NEFA } \\
\hline Arterial concentration $(\mu M)$ & 84.8 & 85.4 & 81.4 & 4.71 & NS \\
\hline $\operatorname{AVD}(\mu M)$ & -10.7 & -13.5 & -14.8 & 2.74 & NS \\
\hline Arterial flow $(\mathrm{mmol} / \mathrm{h})$ & $19.7^{\mathrm{a}}$ & $18.4^{\mathrm{a}}$ & $14.5^{\mathrm{b}}$ & 4.52 & 0.021 \\
\hline Uptake $(\mathrm{mmol} / \mathrm{h})$ & -2.5 & -2.9 & -2.4 & 0.85 & NS \\
\hline
\end{tabular}

comitant. We found that MBF was significantly lower after $19.5 \mathrm{~h}$ of milk accumulation in the udder. The nadir of this effect was not as low as described previously: after $36 \mathrm{~h}$ of milk accumulation, $\mathrm{MBF}$ fell to $74 \%$ of initial MBF versus $50 \%$ in goats (Stelwagen et al., 1994b). However, 3 hypotheses explain the fall in MBF. It could result from a decrease in the metabolic activity of mammary epithelial cells via a local selfregulatory mechanism or from a compression of the blood vessels by milk accumulated in the udder, or a

Table 6. Time-course evolution in arterial concentrations, arteriovenous differences (AVD) of concentrations, extraction rates, arterial flows, and mammary uptake or output of oxygen and carbon dioxide during 36-h milk accumulation in the udder in dairy cows

\begin{tabular}{|c|c|c|c|c|c|}
\hline \multirow[b]{2}{*}{ Item } & \multicolumn{3}{|c|}{ Accumulation period } & \multirow[b]{2}{*}{ SEM } & \multirow{2}{*}{$\begin{array}{l}\text { Period effect } \\
(P \text {-value })\end{array}$} \\
\hline & $0-12 \mathrm{~h}$ & $12-24 \mathrm{~h}$ & $24-36 \mathrm{~h}$ & & \\
\hline \multicolumn{6}{|l|}{ Oxygen } \\
\hline Arterial concentration $(\mathrm{m} M)$ & 6.03 & 6.01 & 6.15 & 0.093 & NS \\
\hline $\operatorname{AVD}(\mathrm{m} M)$ & 1.90 & 1.87 & 1.80 & 0.103 & NS \\
\hline Extraction rate $(\%)$ & 31.7 & 31.2 & 29.3 & 1.93 & NS \\
\hline Arterial flow $(\mathrm{mol} / \mathrm{h})$ & $1.98^{\mathrm{a}}$ & $1.83^{\mathrm{b}}$ & $1.53^{\mathrm{c}}$ & 0.398 & 0.004 \\
\hline Uptake $(\mathrm{mol} / \mathrm{h})$ & $0.60^{\mathrm{a}}$ & $0.55^{\mathrm{a}}$ & $0.44^{\mathrm{b}}$ & 0.098 & 0.022 \\
\hline \multicolumn{6}{|l|}{ Carbon dioxide } \\
\hline Arterial concentration $(\mathrm{m} M)$ & 25.3 & 24.8 & 25.8 & 0.42 & NS \\
\hline $\operatorname{VAD}^{1}(\mathrm{~m} M)$ & 2.73 & 2.81 & 2.45 & 0.098 & NS \\
\hline Output $(\mathrm{mol} / \mathrm{h})$ & $0.90^{a}$ & $0.83^{a}$ & $0.60^{b}$ & 0.178 & 0.069 \\
\hline Respiratory quotient & 1.50 & 1.48 & 1.36 & 0.083 & NS \\
\hline
\end{tabular}

${ }^{a-c}$ Within each row, values with different superscript letters differ at $P<0.05$ (in italics: $P<0.10$ ).

${ }^{1}$ Venoarterial differences of concentrations. 
combination of both. To date, studies have tended to describe the decrease in MBF as resulting from altered mammary metabolic activity (Peaker, 1980; Stelwagen et al., 1994b; Farr et al., 2000), prompted by the fact that MBF does not return to initial levels immediately after the udder is emptied (Stelwagen et al., 1994b; Farr et al., 2000) and because no decrease in MBF occurred when infusing an isosmotic sucrose solution into the lumen to increase intramammary pressure within a physiological range in goats (Peaker, 1980). However, our results argue for the possibility of a physical effect of milk accumulated in the udder on MBF, which would not lead to a decrease in MBF but would prevent its increase.

The arguments for a physical effect are based on several observations. First, the decrease in MBF occurs concomitantly with the impairment of the mammary epithelial permeability, which itself could result from the increase in intramammary pressure caused by milk accumulated in the udder (Stelwagen, 2001). Furthermore, Farr et al. (2000) showed that 26- to 28-h milk stasis in the udder triggered a decrease in the number of capillaries perfused, suggesting blood capillary derecruitment. This capillary de-recruitment could be due to their compression induced by milk accumulated. Second, the decrease in MBF observed in this trial is partly explained by the fact that usual increases in MBF no longer occurred when the milk had heavily accumulated in the udder. This fact can be illustrated in 2 different ways: (1) as a rule, MBF decreases in the $3 \mathrm{~h}$ following a meal, maybe as a response to blood flow being rechanneled toward splanchnic tissues to support digestive and absorption functions, after which it increases again. This increase, which would have been expected with metabolic regulation, although being lower, no longer occurred between 24 and $36 \mathrm{~h}$ of milk accumulation; and (2) in animals milked twice daily, the MBF is higher when the animals are lying down than when they are standing. Here, we found that supine MBF turned out to be significantly higher than upright $\mathrm{MBF}$, averaging $0.72 \mathrm{~L} / \mathrm{min}$ higher over the first $12 \mathrm{~h}$ of milk accumulation. As the milk progressively accumulates, this pattern becomes less clear, or is even reversed. After $12 \mathrm{~h}$ of milk accumulation, MBF measurements were no longer significantly different between supine and upright positions, and by the 24-to-36-h period, supine MBF had become lower in numerical terms than upright MBF. However, even if these observations suggest a physical effect of milk accumulated in the udder on MBF, this might not be a regulatory driver of milk secretion in response to milk accumulation in the udder. This physical effect could coexist alongside metabolic regulation of $\mathrm{MBF}$, as a response to the decreased metabolic activity of the udder.

\section{Decreased Intramammary Metabolic Activity}

In this study, downregulation of mammary metabolic activity was much stronger than the downregulation on mammary nutrient uptake, thus demonstrating the key role of decreased mammary metabolic activity in the decrease of milk secretion. Assuming that measurements performed over the first $12 \mathrm{~h}$ of milk accumulation provide a sound basis for estimating quantitative nutrient uptake in animals milked every $12 \mathrm{~h}$ over $36 \mathrm{~h}$ (data multiplied by 3 ), then the total quantity of nutrient uptake over $36 \mathrm{~h}$ of milk accumulation decreased 12 to $17 \%$, depending on the target nutrient, whereas the total milk and milk protein secretion rates decreased $45 \%$ over the entire 36 -h milk accumulation. The experiment reported here did not study the metabolic activity of mammary epithelial cells per se, but this activity can still be gauged from indicators of nutrient uptake. A decrease in AVD or extraction rate without changes in arterial nutrient concentrations indicates changes in mammary metabolic activity, the udder adjusting its extraction efficiency according to its nutrient requirements (Miller et al., 1991; Guinard and Rulquin, 1994). Arteriovenous differences, measured in this study, did not vary significantly but extraction rates showed that mammary metabolic activity decreased before $24 \mathrm{~h}$ of milk accumulation in the udder. Indeed, the acetate extraction rate decreased between 12 and $24 \mathrm{~h}$ of milk accumulation in the udder. This decreased metabolic activity was associated with lower mammary uptake or release of nutrients mostly due to the impaired MBF. The quantitative decrease in nutrient uptake was observed for glucose, acetate, and BHBA between 12 and $24 \mathrm{~h}$ of milk accumulation and for all nutrients except NEFA between 24 and $36 \mathrm{~h}$. Similarly, the same variations were found, but on the second day after milking was stopped in goats (Kuhn and Linzell, 1970; Fleet and Peaker, 1978).

Very few studies have investigated the decreased metabolic activity of mammary epithelial cells during the acute-phase regulatory response to milk accumulation in the udder of dairy ruminants. To the best of our knowledge, this metabolic activity has essentially only been described in time-course trials designed to highlight cell remodeling and apoptosis effects in mammary tissue during milk accumulation in the udder (Singh et al., 2005, 2008; Ben Chedly et al., 2009). In these trials, the indicator used to describe metabolic activity was the expression levels of specific milk protein genes, and more rarely protein levels, whereas enzyme activity has never yet, at least to our knowledge, been used. Gene expression analysis shows that mRNA expression of milk protein genes is quickly regulated, reportedly decreasing within at least $24 \mathrm{~h}$ of milk accumulation in 
dairy cows for $\mathrm{CN} \alpha \mathrm{s} 1$ and $\alpha-\mathrm{LA}$ and $36 \mathrm{~h}$ for $\beta$ - and $\kappa-C N$ (Singh et al., 2008). Similar results have been reported in goats for $\alpha-\mathrm{LA}$ and $\kappa-\mathrm{CN}$ on mammary tissue biopsies sampled after $36 \mathrm{~h}$ of milk accumulation (Ben Chedly et al., 2009). However, to date, no results have been reported for the proteins involved in milk fat synthesis.

\section{Less Downregulated Milk Fat Yield}

The strong increase in milk fat content found in this study is probably due to milk fat synthesis being affected less compared with lactose and proteins. Indeed, it seems unlikely that fat synthesis was decreased to the same extent, and accumulated in the udder because of the large size of fat globules such that they could not pass through the mammary epithelium. No increase in milk CN content or tendency was observed here. This would have been expected because of their micellar structure.

The strong increase in fat content could be due to a lower decrease in the number or activity, or both, of enzymes responsible for fat synthesis compared with enzymes involved in synthesis of other milk components. Our data do not provide information about milk secretion throughout the extended interval and the timing of inhibition of secretion of fat and aqueous phases. However, with regard to uptake of nutrients by the udder, which is fairly related to milk component synthesis and secretion, glucose, acetate, and BHBA began to decrease in the same 12-to-24-h period of milk accumulation. Because acetate and BHBA are both precursors for milk short- and medium-chain fatty acids, this suggests that the decrease in milk fat secretion could coincide with the decrease in the aqueous phase. Therefore, milk fat synthesis could be simultaneously decreased but could be relatively less affected than the aqueous phase in the course of milk accumulation, leading to a progressive exacerbated fat concentration in milk.

As a result, this was associated with a modified partitioning of glucose between mammary metabolic pathways. The ratio number of moles of lactose $\mathrm{C}$ exported in milk-to-number of moles of glucose $\mathrm{C}$ taken up by the udder fell from $90 \%$ over the 12-h interval to $53 \%$ over the 36 -h interval $(P=0.0321)$. However, using lactose content measured on 36 -h milk to estimate this ratio leads to an underestimation of mammary lactose secretion because of lactose leakage into the blood compartment. Correcting this 36 -h lactose content by assigning the 12-h-interval lactose content still highlights a decrease, falling from 90 to $58 \%(P=0.0499)$. This decrease in the proportion of glucose taken up and converted to lactose is large and this is the first study to report such variations in the potential contribution of glucose to lactose supply. This large variation could illustrate a transient response corresponding to the acute-phase adaptation of metabolic activity in mammary epithelial cells in response to a highly extended milking interval. Because the glucose taken up cannot participate in lactose synthesis, it could potentially be oxidized or converted to glycerol and subsequently incorporated in the milk triglycerides. Given the important increase in milk fat yield found in this trial, the hypothesis of a strongly enhanced conversion toward glycerol synthesis appears highly likely. GuinardFlament et al. (2007b) previously reported improved glucose-to-glycerol conversion in response to extending milking interval. This improvement, estimated after 6 d of treatment, remained mild, only increasing from 6.5 to $8.8 \%$ between cows milked every 8 and $24 \mathrm{~h}$, respectively. In the same way, a greater conversion of acetate and BHBA uptake toward short- and mediumchain fatty acid synthesis was reported (Delamaire and Guinard-Flament, 2006a; Guinard-Flament et al., 2007b).

The biological significance of the strong increase in milk fat content warrants further investigation to better understand the driving force of milk fat modifications. Indeed, it could be interpreted as an udder adaptation designed to curtail the decrease in milk energy value for newborns while milk production is significantly reduced (Davis et al., 1999). If true, this suggests that this metabolic pathway has priority in the udder. In another way, from a nutritional point of view, lower inhibition of fat synthesis enabled utilization of the energy made freshly available by the decrease in milk secretion and milk proteins, suggesting that milk fat synthesis is a buffer metabolic pathway able to absorb lack or excess of energy supplied to the udder.

\section{CONCLUSIONS}

In the present study, the timing of changes in the permeability of the mammary epithelium and in $\mathrm{MBF}$ were concomitant, and occurred at the time known to mark the point when milk secretion rate began to fall in response to milk accumulation in the udder. These changes could result from the increased intramammary pressure, making MBF unable to increase as it used to, because of blood vessel compression by the milk accumulated in the udder. However, the physical effect of milk accumulated in the udder on MBF has to be demonstrated, given that its role in the downregulation of milk synthesis could remain limited. Here, the mammary uptakes of nutrients decreased less than milk yield and milk protein yield, underlining the involvement of intracellular regulation in the decrease in milk secre- 
tion. The sharp drop in mammary conversion of glucose toward lactose synthesis associated with slight decrease in milk fat suggested a highly modified partitioning of nutrients between metabolic pathways.

\section{ACKNOWLEDGMENTS}

The authors thank the staff at the INRA Mejusseaume experimental farm (Le Rheu, France) for help with animal care and handling. We also thank André Cozien, Daniel Chevrel, and Maryvonne Texier (INRA, Le Rheu, France), Nicole Huchet, Sylvie Marion, and Thibaud Le Mouel (INRA, St-Gilles, France) for technical assistance, Luc Delaby and Cécile Sauder (INRA, St-Gilles, France) for their contributions to the statistical analysis, Naveed Ul Haque (INRA, StGilles, France), and A-T-T Scientific Editing Services (Clermont-Ferrand, France) for proofreading the manuscript.

\section{REFERENCES}

Bauchard, D., and F. Duboisset. 1983. Utilisation des colonnes capillaires de verre pour l'analyse des acides gras du lait. Cah. Tech. Inst. Natl. Rech. Agron. Bull. Liaison Int. 1:37-46.

Ben Chedly, H., P. Lacasse, P. G. Marnet, S. Wiart-Letort, L. Finot, and M. Boutinaud. 2009. Cell junction disruption after $36 \mathrm{~h}$ milk accumulation was associated with changes in mammary secretory tissue activity and dynamics in lactating dairy goats. J. Physiol. Pharmacol. 60:105-111.

Davis, S. R., V. C. Farr, P. J. Copeman, V. R. Carruthers, C. H. Knight, and K. Stelwagen. 1998. Partitioning of milk accumulation between cisternal and alveolar compartments of the bovine udder: Relationship to production loss during once daily milking. J. Dairy Res. 65:1-8.

Davis, S. R., V. C. Farr, and K. Stelwagen. 1999. Regulation of yield loss and milk composition during once-daily milking: A review. Livest. Prod. Sci. 59:77-94.

Delamaire, E., and J. Guinard-Flament. 2006a. Increasing milking intervals decreases the mammary blood flow and mammary uptake of nutrients in dairy cows. J. Dairy Sci. 89:3439-3446.

Delamaire, E., and J. Guinard-Flament. 2006b. Longer milking intervals alter mammary epithelial permeability and the udder's ability to extract nutrients. J. Dairy Sci. 89:2007-2016.

Farr, V. C., C. G. Prosser, and S. R. Davis. 2000. Effects of mammary engorgement and feed withdrawal on microvascular function in lactating goat mammary glands. Am. J. Physiol. Heart Circ. Physiol. 279:H1813-H1818.

Fleet, I. R., and M. Peaker. 1978. Mammary function and its control at the cessation of lactation in the goat. J. Physiol. 279:491-507.

Guinard, J., and H. Rulquin. 1994. Effects of graded amounts of duodenal infusions of lysine on the mammary uptake of major milk precursors in dairy cows. J. Dairy Sci. 77:3565-3576.

Guinard, J., H. Rulquin, and R. Vérité. 1994. Effect of graded levels of duodenal infusions of casein on mammary uptake in lactating cows. 1. Major nutrients. J. Dairy Sci. 77:2221-2231.

Guinard-Flament, J., E. Delamaire, P. Lamberton, and J. L. Peyraud. 2007a. Adaptations of mammary uptake and nutrient use to oncedaily milking and feed restriction in dairy cows. J. Dairy Sci. 90:5062-5072.
Guinard-Flament, J., S. Lemosquet, and E. Delamaire. 2007b. Estimation of the intra-mammary metabolic fate of glucose and acetate in response to longer milking intervals in dairy cows. Pages 151-152 in ISEP-2nd International Symposium on Energy and Protein Metabolism and Nutrition, Vichy, France. EAAP Publication no. 124 Wageningen Academic Publishers, Wageningen, the Netherlands.

Institut National de la Recherche Agronomique. 1989. Feeding standards for ruminants. Pages 15-22 in Ruminant Nutrition. Recommended Allowances and Feed Table. J. Libbey, ed. Eurotext, London, UK.

Kjeldahl, J. 1883. A new method for the determination of nitrogen in organic bodies. Z. Anal. Chem. 22:366-382.

Komara, M., M. Boutinaud, H. Ben Chedly, J. Guinard-Flament, and P. G. Marnet. 2009. Once-daily milking effects in high-yielding Alpine dairy goats. J. Dairy Sci. 92:5447-5455.

Kuhn, N. J., and J. L. Linzell. 1970. Measurement of the quantity of lactose passing into mammary venous plasma and lymph in goats and in a cow. J. Dairy Res. 37:203-208.

Levieux, D. 1991. Dosage des IgG du lait de vache par immunodiffusion radiale semi-automatisée, pour la détection du colostrum, des laits de mammites ou de fin de gestation. I. Mise au point de dosage. Lait 71:327-338.

Miller, P. S., B. L. Reis, C. C. Calvert, E. J. DePeters, and R. L. Baldwin. 1991. Patterns of nutrient uptake by the mammary glands of lactating dairy cows. J. Dairy Sci. 74:3791-3799.

Peaker, M. 1980. The effect of raised intramammary pressure on mammary function in the goat in relation to the cessation of lactation. J. Physiol. 301:415-428.

Rémond, B., and D. Pomiès. 2005. Once-daily milking of dairy cows: A review of recent French experiments. Anim. Res. 54:427-442.

Singh, K., S. R. Davis, J. M. Dobson, A. J. Molenaar, T. T. Wheeler, C. G. Prosser, V. C. Farr, K. Oden, K. M. Swanson, C. V. C. Phyn, D. L. Hyndman, T. Wilson, H. V. Henderson, and K. Stelwagen. 2008. cDNA microarray analysis reveals that antioxidant and immune genes are upregulated during involution of the bovine mammary gland. J. Dairy Sci. 91:2236-2246.

Singh, K., J. Dobson, C. V. C. Phyn, S. R. Davis, V. C. Farr, A. J. Molenaar, and K. Stelwagen. 2005. Milk accumulation decreases expression of genes involved in cell-extracellular matrix communication and is associated with induction of apoptosis in the bovine mammary gland. Livest. Prod. Sci. 98:67-78.

Stelwagen, K. 2001. Effect of milking frequency on mammary functioning and shape of the lactation curve. J. Dairy Sci. 84(E. Suppl.):E204-E211.

Stelwagen, K. S. R. Davis, V. C. Farr, S. J. Eichler, and I. Politis 1994a. Effect of once daily milking and concurrent somatotropin on mammary tight junction permeability and yield of cows. J. Dairy Sci. 77:2994-3001.

Stelwagen, K., S. R. Davis, V. C. Farr, C. G. Prosser, and R. A. Sherlock. 1994b. Mammary epithelial cell tight junction integrity and mammary blood flow during an extended milking interval in goats. J. Dairy Sci. 77:426-432.

Stelwagen, K., V. C. Farr, H. A. McFadden, C. G. Prosser, and S. R. Davis. 1997. Time course of milk accumulation-induced opening of mammary tight junctions, and blood clearance of milk components. Am. J. Physiol. 273:R379-R386.

Stelwagen, K., V. C. Farr, G. D. Nicholas, S. R. Davis, and C. G Prosser. 2008. Effect of milking interval on milk yield and quality and rate of recovery during subsequent frequent milking. Livest. Sci. 2-3:176-180.

Stelwagen, K. D. C. van Espen, G. A. Verkerk, H. A. McFadden, and V. C. Farr. 1998. Elevated plasma cortisol reduces permeability of mammary tight junctions in the lactating bovine mammary epithelium. J. Endocrinol. 159:173-178.

Wheelock, J. V., J. A. F. Rook, F. H. Dodd, and T. K. Griffin. 1966 The effect of varying the interval between milkings on milk secretion. J. Dairy Res. 33:161-176. 